\title{
Quality-of-Life Studies in Natural and Built Environment: Challenges and emerging issues
}

\author{
Mohammad Abdul Mohit \\ Kulliyyah (Faculty) of Architecture and Environmental Design, \\ International Islamic University Malaysia (IIUM), Kuala Lumpur, Malaysia \\ mamohit@iium.edu.my; mohd.mohit@gmail.com
}

\begin{abstract}
Quality of life (QOL) is a multifaceted concept beingused by a variety of disciplines. Theoretical aspect of QOL relates to happiness, life satisfaction and needs satisfaction approaches. It is a complex construct, and its measurement is multidimensional. QOL researchers use either objective or subjective measurement or a combination of two, through modeling exercises. It is a growing area of research. Many disciplines have embedded QOL within their researches. Nevertheless, in Built Environment, such as Architecture, Landscape Architecture, Quantity Surveying, Applied Art, QOL researches are few. Therefore, it is recommended that $\mathrm{QOL}$ research should be embedded in environmental design discipline.
\end{abstract}

Keywords: Quality of life, built environment; happiness; life satisfaction.

eISSN 2398-4295 @ 2018. The Authors. Published for AMER ABRA cE-Bs by e-International Publishing House, Ltd., UK. This is an open-access article under the CC BY-NC-ND license (http://creativecommons.org/licenses/bync-nd/4.0/). Peer-review under responsibility of AMER (Association of Malaysian Environment-Behaviour Researchers), ABRA (Association of Behavioural Researchers on Asians) and cE-Bs (Centre for EnvironmentBehaviour Studies), Faculty of Architecture, Planning \& Surveying, Universiti Teknologi MARA, Malaysia.

DOI: http://dx.doi.org/10.21834/ajbes.v3i10.89 


\subsection{Introduction}

The term Quality of life (QOL) is used and understood by most people as 'goodness of life' and being able to live successfully and happily within the environment (Brown and Brown, 2005). QOL should not be confused with the income based concept of standard of living. Instead, standard indicators of QOL include not only wealth and employment, but also the built environment, physical and mental health, education, recreation and leisure time, and social belonging (Gregory et al., 2009).

The QOL construct has a complex composition, so it is perhaps not surprising that there is neither an agreed upon definition nor a standard form of measurement (Cummins, 1997) and this has made studying it more challenging and stimulating. It is argued that different people in different regions of the world have defined QOL differently according to their own perceptions, which to a certain extent is influenced by their own cultures, social environment, and level of economic development. Individuals or communities in the developed countries have different perceptions with respect to what constitutes the level of comfort, enjoyment and ability to pursue their daily activities than their counterparts in the developing or underdeveloped countries.

Although more than a dozen definitions of QOL exist, WHO in 1991 developed an international cross-cultural comparable quality of life assessment instrument called WHOQOL-BREF. The assessment is based on the individual's perception in the context of their culture and value systems and their personal goals, standards and concerns. The WHOQOL-BREF group defines QOL as-

"An individual's perception of his/her position in the context of culture and value systems in which they live in and in relation to their goals, expectations, standards and concerns. It is a broad-ranging concept incorporating, in a complex way, the person's physical health, psychological state, level of independence, social relationships, personal beliefs and relationships to salient features of the environment" (WHOQOL Group, 1998).

\subsection{Historical Perspective of Qol Studies}

The history of QOL discussion can be traced back as early as the era of the popular Greek philosophers such as Plato (427-347 BC) and Aristotle (384-322 BC) (Anderson, 2004). According to Sirgy, et al. (2006), Plato started working on QOL by examining the nature of the good-life of an individual or society and proposed that individuals who live in harmony are happier and stronger compared to those who are in conflicts among themselves. Aristotle introduced objective and subjective indicators of a good or happy life since he argued that the subjective indicators such as attitudes, feelings and beliefs did not form a complete measure of a happy life.

The work of Maslow's (1954) hierarchy of human needs (Table 3) appears to suggest that the fulfillment of needs is fundamental to the good life, and it creates more development on needs satisfaction theories which currently are very much referred to inQOL literature.QOL was gauged using a material level of living such as GDP related measures which according to Rapley (2003), is inadequate to represent the measurement of QOL However, the conception of modern QOL begins with the development of the 'social 
indicators movement' during the 1960s and 1970s, when there were theincreasing discontentment amongst many economists and sociologists who were using the traditional economic measures -GDP, income, as indicators to measure societal development (Sirgy, 1996).The study of QOL concept then passed to medical fields in the 80 s, focusing on the functional indicators of patients' health-related well-being. From 1990 and onwards, the study of QOL received growing interest among the researchers in the field of social sciences, built environment, urbanization, marketing. According to Marans and Stimson (2011), QOL studies are experiencing a resurgence of interest in contemporary times, driven not only by the research community but also by public policy, and a concern in urban governance, planning and management which are directed to make cities more competitive, achieve sustainable development, and enhance the well-being of residents. UN-HABITAT (2012) in a recent report has used $\mathrm{QOL}$ as an important component of measuring city prosperity index and states that "cities that improve QOL experience higher levels of prosperity; they are also likely to find themselves more advanced in terms of sustainability".

\subsection{Qol Study Dimensions}

QOL is a multifaceted concept which has been used by a variety of disciplines for benchmarking and development policy purposes. Sirgy (2001) argues that the term QOL is a rich concept and can be construed in different perspectives such as health approach, needs approach, QOL as happiness versus life satisfaction and the resource management approach. Over the years, the study of QOL has attracted the attention of researchers from a wide range of academic disciplines as well as interest among policy makers, planners and others in the environmental design fields. The concept is certainly interdisciplinary, and it is recognized as warranting interdisciplinary study (Marans, 20102). Table 1 documents use of QOL for research and development policy purposes.

Table 1. Disciplines Related to the QOL Studies.

\begin{tabular}{|c|c|c|c|}
\hline Disciplines & Major concern & Measurement & Nomenclature \\
\hline Economics / Political Science & Income, poverty & Objective & QOL \\
\hline Sociology/Psychology & $\begin{array}{l}\text { Individual/ } \\
\text { Community well- } \\
\text { being }\end{array}$ & Subjective & QOL/QOWL \\
\hline Health studies & Individual well-being & Subjective & HR-QOL \\
\hline Housing & Housing satisfaction & Subjective well-being & QOL-Housing \\
\hline Marketing & Product satisfaction & Subjective well-being & QOL-Marketing \\
\hline Cities level analysis & Livability & Objective & QOL-livability \\
\hline Urban analysis & $\begin{array}{l}\text { Urban } \\
\text { condition }\end{array}$ & Objective/ subjective & QOUL \\
\hline
\end{tabular}

Source: Authors adaptation based on various studies.

QOL is a pervasive concept and can be applied at different spatial levels, for research and policy purposes. Table 2 presents the spatial levels at which QOL studies are embedded in the fields of the built environment for policy pursuits. 
Table 2. QOL Studies conducted at various spatial levels.

\begin{tabular}{|llll|}
\hline Spatial level & Approach & Measurement & Dimension/ Comp \\
\hline International & Indexing & Objective & Multidimensional \\
National & Indexing & Objective & Multidimensional \\
Regional & Indexing & Objective/subjective & Multidimensional \\
City / Urban & Multiple communities & Objective/subjective & Multidimensional \\
Community & Multiple neighborhood & Objective/subjective & Multidimensional \\
Neighborhood & Multiple groups & Objective/subjective & Multidimensional \\
Building/Group & Households/families & Subjective & Multidimensional \\
\hline
\end{tabular}

Source: Authors adaptation based on various studies

\subsection{Theoretical Perspective Of Qol}

\section{Theoretical Perspective}

QOL is a broad concept which is concerned with overall well-being of people in the society, and it can be studied from different theoretical perspectives (Mohit, 2013a). Three important perspectives are-
A. Happiness and Life Satisfaction Approach.
B. Needs Satisfaction Approach.
C. Life Satisfaction based on Need Satisfaction.

\section{Happiness and Life Satisfaction Approach}

Although happiness and life satisfaction are not the same, they are mutually interrelated with the notion of QOL.Happiness is defined as the affective or feeling state of the individual, and it is derived from the positive and negative emotional reactions experienced from life events (Sirgy and Lee, 2006). On the other hand, life satisfaction is defined as the outcome of evaluation of one's current life situations or accomplishments against certain standards of comparisons such as one's ideal life, expectations of personal utility, individual goals, values, needs, opulence and the lives of significant others. Usually, life satisfaction is measured based on an individual evaluation on the different aspects of life domain such as family life, financial life, consuming life and social life, given that these life domains are important to them. It is a long-term cognitive appraisal of the past, present and overall life events, and it is considered to be relatively more stable among older age groups of people than the younger ones (Campbell, et al., 1976).

\section{Needs Satisfaction Approach}

According to this approach, an individual achieves a certain level of QOL based upon the extent to which his/her basic needs are met. Maslow's (1954) work sets the foundation for development on the needs satisfaction theories. Arndt (1981) suggests these needs to be categorized into Physical needs, Social needs and Self- actualization needs. The theory 
proposed by Allards (1993) is to overcome the issue of the fixed arrangement of the needs in the sequence of hierarchy of order postulated by Maslow's hierarchy of needs, and he proposed three types of needs. Table 3 summarizes the types of needs satisfaction according to the three different authors.

Table 3. Needs satisfaction theories

\begin{tabular}{|lll|}
\hline Maslow (1954) & Arndts (1981) & Allards (1993) \\
\hline $\begin{array}{l}\text { Physiological needs } \\
\text { Safety needs }\end{array}$ & $\begin{array}{l}\text { Physical needs } \\
\text { Belongings needs }\end{array}$ & Social needs \\
$\begin{array}{l}\text { Self-esteem needs } \\
\text { Self-actualization needs }\end{array}$ & Self-actualization needs & Loving needs \\
\hline
\end{tabular}

Source: Maslow, 1954; Arndts, 1981; Allards, 1993

\section{Life Satisfaction Based on Need Hierarchy Approach}

Sirgy (1995) developed a QOL model in which life satisfaction measure was drawn from Maslow's (1954) need hierarchy theory. The model is based on the theoretical notion that the greater level of satisfaction of lower- and higher-order need, the greater the level of life satisfaction. Lower-order needs are related to biological sustenance and safety while higherorder needs are related to social belongings, esteem and self-actualization. Hence, QOL can be defined in terms of the hierarchical need satisfaction level of most of the members of a society. The higher the need satisfactions of a majority of people in a society, the greater the QOL of that society. The model was tested in 1,226 adults drawn from the United States, Canada, Australia, Turkey and China, along with other life satisfaction and demographics. The results provided evidence of the construct validity of the need hierarchy measure of life satisfaction.Other theoretical perspectives applied to recently developed QOUL studies are - optimal centrality theory, territorial social indicators.

\subsection{Qol Analysis Framework Through Modeling Approach}

QOL construction can be described by its components, and they are termed as domains. Different researchers suggest different sets of QOL componentsdepending on the perspective and purpose of their studies. Underneath each domain there are several indicators that provide details of the domain. These domains can be further grouped into two categories - external and internal. External domain involves a study of factors such as social, economic, and educational health, within the environment around the individuals. On the other hand, internal domain concentrates on factors that occur inside individuals' heads, such as personal health and internal psychology.

In their seminal work, Campbell et al (1976) developed a model showing the relationship between domain satisfaction and life satisfaction (Fig.1). The model rest on four principles (1) the experience of people is derived from their interaction with the associated objective attributes, (2) the subjective experiences of people are different from the objective attributes; (3) people respond to their experiences with the environment, and (4) the level of satisfaction in various life domains contributes to the overall QOL experience. In essence, the model 
specified a series of life domain and satisfaction measure of those domains, which in turn could be influenced by a range of individual characteristics and individual standard of comparison (Marans, 2012). The model proposed by Campbell et al. (1976) suggested that satisfaction with living could be viewed at multiple level of analysis, such as housing, neighborhood, city, region and nation (Marans, 2012).

Marans (2012) also developed several models for neighborhood satisfaction and individual well-being linking to health and community quality. The benefits of using modeling approaches in QOL research have been summarized by McCrea, Western and Stimson (2011). These are -

A. Models are able to accommodate a large number of factors that influence the levels of satisfaction.

B. Models allow for the comparison at different geographic levels of living.

C. Models allow the satisfaction of a domain to contribute to the satisfaction of another domain.

D. It is possible for the level of satisfaction in one domain to influence satisfaction in other domains through the spill-over effects.

Raphael et al. (2001) studied QOL from the community perspective and proposed that the QOL community of life encompasses three domains - Being (one who is), Belonging (connection with one's environment) and Becoming (achieving personal goals, hopes and aspirations), 9 sub-domains and 25 indicators. Schalock (2004) suggested eight core QOL domains or core indicators of QOL with 19 indicators although there exist similarities and overlap with the one suggested by Raphael et al. (2001). These are - Emotional Well-being, Interpersonal Relations, Material Well-being, Personal Development, Physical Well-being, Self-determination, Social Inclusion and Rights.

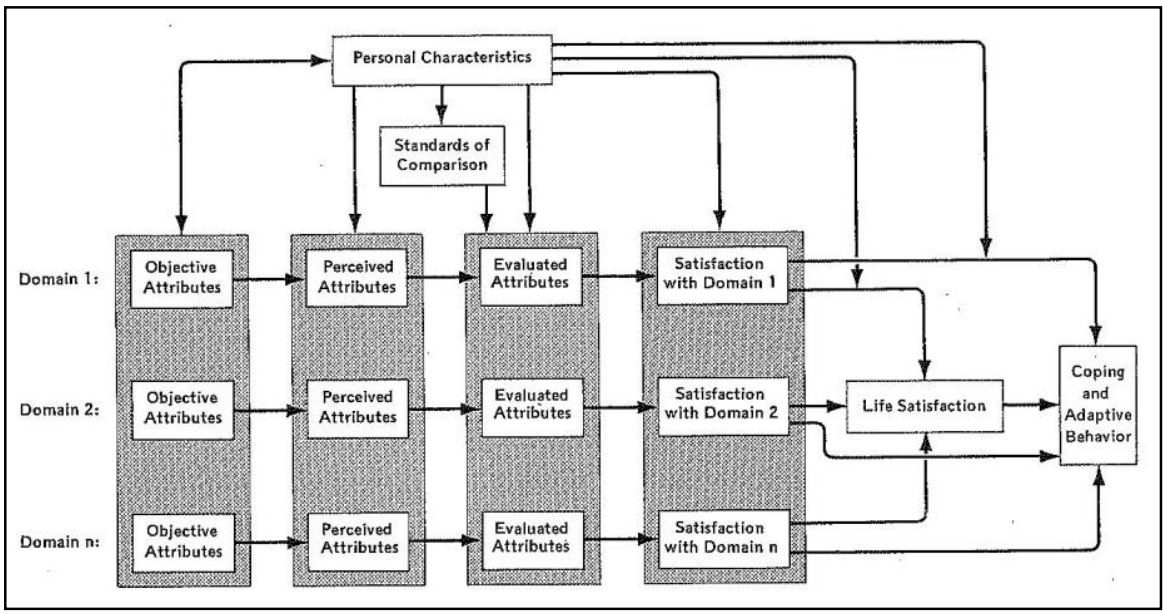

Figure 1: Model showing the relationship between domain satisfaction and life satisfaction (Source: Campbell, et al. 1976). 


\subsection{Qol And Sustainable Development}

Sustainable development aims at ensuring a better quality of life for everyone, at present and for generations in the future. Sustainable development means recognizing that the economy, the environment and social well-being are interdependent. It means protecting and, where possible, enhancing the environment, for its own sake and also because a damaged environment will sooner or later hold back economic development and affect people's QOL. It is about ensuring to satisfy people's basic needs, such as providing affordable homes and safe streets and giving people the opportunity to achieve their potential through education, information, participation, good health and employment. It requires a strong economy to create the wealth that allows needs to be satisfied, at present and in the future. TAC Social Issues Subcommittee (2004) suggests a "Three-legged Stool of Sustainability", with three major basic domains - social, economic and environmental. Social indicators are used to measure social well-being that describes the current analysis of social conditions and monitor the social changes over time. Economic indicators are used to assess the performance of a country or region in the production and distribution of goods and services over time. Environmental indicators are used to provide information in order to control the pressures created by social and economic development on the environment, and to ensure that a country's development achieves balance or sustainability. The complex interactions between social, economic and environmental indicators contribute to the construct of QOL. Therefore, maintaining a balance between social, economic and environmental components of development is crucial to ensure sustainable development in order to ensure a better QOL.

\subsection{QOL AND ITS MEASUREMENT}

$\mathrm{QOL}$ is a complex construct and its measurement is multidimensional in nature, composed of many indicators. Cummins (1996) suggests that there are two basic approaches to the definition and measurement of quality of life... one regards the construct as a single unitary entity while the other considers it to be composed of discrete domains. The former specifies QOL at an aggregate level by objective measures while the latter focuses at the disaggregated or individual level.

Table 4. Subjective, Objective and Behavioral Indicators of QOL Measurements.

\begin{tabular}{|c|c|c|}
\hline $\begin{array}{l}\text { Frequently used objective social } \\
\text { indicators }\end{array}$ & $\begin{array}{l}\text { Frequently used subjective social } \\
\text { indicators }\end{array}$ & $\begin{array}{l}\text { Behavioral indicators } \\
\text { (QOUL) }\end{array}$ \\
\hline $\begin{array}{l}\text { Life expectancy } \\
\text { Crime rate } \\
\text { Unemployment rate } \\
\text { Gross Domestic Product } \\
\text { Poverty rate } \\
\text { School attendance } \\
\text { Working hours per week } \\
\text { Perinatal mortality rate } \\
\text { Suicide rate }\end{array}$ & $\begin{array}{l}\text { Sense of community } \\
\text { Material possessions } \\
\text { Sense of safety } \\
\text { Happiness } \\
\text { Satisfaction with 'life as a whole' } \\
\text { Relationship with family } \\
\text { Job satisfaction } \\
\text { Sex life } \\
\text { Perception of distributional justice } \\
\text { Class identification } \\
\text { Hobbies and club membership }\end{array}$ & $\begin{array}{l}\text { Public transit use } \\
\text { Participation in sports } \\
\text { Amount of walking \& bicycling } \\
\text { Visited to cultural amenities \& events } \\
\text { Visits to parks } \\
\text { Visits to cultural amenities \& events } \\
\text { Visits to parks } \\
\text { Visits to health clinics/ doctors } \\
\text { Amount of neighboring } \\
\text { Participation in voluntary organizations } \\
\text { Participation in local decision-making } \\
\text { Residential mobility organizations }\end{array}$ \\
\hline
\end{tabular}

(Sources: Rapley, M. 2003, p. 11, Marans and Stimson, 2011, p. 3). 
Subjective measures focus on measuring subjective well-being based on the individual evaluations and perceptions of life which are used to measure the QOL construct. The researcher use primary data to gain insights into what a person considers being important to the well-being or satisfaction in his life. Subjective QOL is about feeling good and being satisfied with things in general. In summary, subjective QOL measures are concerned with measuring aspects related to the cognitive experience (judgement, beliefs, evaluation), affective aspects of experience (feeling) and behavior dimension.

Objective measures are those that can be observed and measured within the public domain using indicators such as physical properties and frequencies. Objective measurement includes economic status, politics, health and education, environment and social condition. The objective measures of QOL allow researchers to use secondary data. However, the use of objective measures may pose problems with the validity issues. A group of indicators mentioned by Marans et al. (2011) is termed as behavioral indicators, which are for use in QOUL studies.

The choice on the use of either a subjective or an objective measure for a QOL study depends on the research interest and design. Subjective and objective measures complement each other, and they are needed in the QOL study. While both measurement methods offered insight into the QOL issue, there are a number of limitations to using either of these approaches separately, what seems best, then, is to attempt to approach QOL that combines objective and subjective approaches (Costanza et al., 2008). However, some empirical studies commented that direct links between objective and subjective indicators were found to be weak (McCrea, et al., 2011).

\subsection{Qol Research In Malaysia}

QOL studies in Malaysia are discrete studies with disciplinary orientations that are designed to conduct in-depth analysis of the problem pertaining to the topic of research. Micro level QOL research in Malaysia started in 1987 with Husna and Nurijan (1987) who did the first study of residential satisfaction of public low-cost flat dwellers in Kuala Lumpur. Mastura, et al. (undated) conducted a cross-section of project type, house price and length of residency which influenced housing satisfaction among the residents of Penang Development Corporation projects. Nurizan (1993) reported that the residents of low-cost housing in Johor Bahru were only satisfied with public transport, and distance of housing from the city, but they were not satisfied with the size, rental, and crowding in the house. Halimah and Lau (1998) compared the perceived concept of home aspired between Malay and Chinese housewives in low-cost housing in Selangor and found that there were significant differences between the two groups.

Salleh (2008) studied residential satisfaction and found that the neighborhood factors are the dominant factors which affect housing satisfaction in private low-cost housing in Malaysia. Oh (2000) studied middle income households in Bandar BaruBangi, Malaysia, and found that while the residents were satisfied with the space and price of their houses, but they were not satisfied with the size of kitchen, plumbing and public facilities such as recreational areas, playground, taxi and bus services in the housing area. Mohit, et al. (2010), studied residential 
satisfaction of newly designed public low-cost housing and found that the residents are moderately satisfied with dwelling unit supporting services, followed by public and neighborhood facilities than dwelling unit features and social environment. Mohit and NurulNazyddah (2011) studied Selangor Zakat Board-funded low income housing in Selangor State and found that the agency has been successful in providing a moderate level of satisfaction with three types of housing units in the State.

Recent QOL studies in Malaysia have used subjective measurements based on respondents' perception. HafazahAbd Karim (2012) studied four domains of QOL in low cost housing, in Shah Alam. Sarina Muhd Noor and MohdAdli Abdullah (2012) studied Quality of Work Life (QWL) in a multinational firm in Malaysia and found that job satisfaction, job involvement, and job security exert significant relationships with QWL. Wan Ahmad Aizzat Wan Zaidi et al. (2012) studied QOL in patients with HIV infection and AIDS living in HIV shelters and found that although many patients were fearful about their future, but they agreed to the good QOL in the shelters. SaripahAbd Latif et al (2013) investigated the effects of situational factors on recycling behavior in order to determine the QOL.

The AicQoL2013 Conference, the first of its kind in Malaysia includes 89 papers. From a title search containing the word 'QOL', it is found that only $20(23 \%)$ papers deal with the various dimensions of QOL in Malaysia. A detailed study of the title contents indicates that there are HR-QOL-4, QOL-SD-2, QOL-Construction-1, QOL-Housing-4, QOUL-6, and QOWL-3 studies.

The foregoing survey of QOL studiesindicates that micro level studies pertaining to disciplinary concerns and utilizing subjective approach dominate the scenario of QOL research in Malaysia. Micro level research is dominated by HR - QOL studies, and in built environment, it is dominated by QOL-Housing studies. Therefore, there is a need to embed QOL in other branches of the built environment discipline, along with the promotion of macro, regional and local/ city level QOL studies (Mohit, 2014).

\subsection{Conclusion}

QOL is a growing field of research. Many disciplines have already adopted and adapted QOL within their research domain. It appears that QOL research attracts attention and interest of many parties and understanding of QOL require endless efforts. However, efforts to improve understanding about QOL should not be limited to one discipline only, and it should be extended to other disciplines. Some authors (e.g. Marans and Stimson, 2011) have identified several challenges, which QOL studies are now facing and to which future studies may be directed. These are -

A. QOL studies should be focused towards examining cross-cultural differences or similarities from surveys conducted in different parts of the world.

B. QOL studies should be promoted through additional outlets of research. Besides, international scholarly publications, efforts should be made to present study results in local media or on the Web. 
C. Efforts should be made to ensure that local government officials are made aware of QOL study findings, so as to inform the multitude of planning and policy decisions that need to be made in their respective jurisdictions.

D. In the Built Environment discipline such as Architecture, Landscape Architecture, Quantity Surveying, Construction Management, Applied Arts, QOL-related researches are virtually absent. QOL research should be embedded in these branches of the Built Environment.

In the end, this paper expects to inspire the promising researchers to undertake QOL studies, linking the social sciences with the environmental design discipline.

\section{References}

Allardt, E. Ed. (1993). Having, Loving, Being: An Alternative to the Swedish Model of Welfare Research, in M. Nussbaum and A. Sen (Eds). The Quality of Life. Oxford: Clarendon Press, pp.88-94.

Arndt, J. (1981). Marketing and the Quality of Life.Journal of Economic Psychology, 1 pp.283-301.

Anderson, B. (2004). Information Society Technologies and Quality of life - A literature review and a tool for thought. Working Paper. Ipswich: University of Essex.

Brown, R.J. and Brown, I. (2005).The application of quality of life.Journal of Intellectual Disability Research, 49 (10): 718-727.

Campbell, A.C., Converse, P., and Rogers, W.L. (1976).The Quality of American Life: Perceptions, Evaluations and Satisfactions. New York: Russell Sage Foundation.

Costanza, R. et al (2008). An Integrative Approach to Quality of Life Measurement, Research, and Policy, SAPIENS, $1(1)$, pp. 17-21.

Cummins, R.A. (1997). Comprehensive Quality of Life Scale: Manual. Melbourne: Deakin University.

Gregory, D., Johnston, R., Pratt, G. (Eds) (2009). Quality of Life, in Dictionary of Human Geography. Oxford: WileyBlackwell.

Jones, A. (2002). A guide to doing quality of life studies. UK: School of Public Policy, University of Birmingham.

Kahneman, D. (1999). Objective happiness, in Kahneman, D., Diener, E.And Schwara, N. (Eds).Well-being: The Foundations of Hedonic Psychology. New York: Sage Publications.

Marans, R.W. (2012)). Quality of Urban Life Studies: An Overview and Implications for Environment-Behavior Research.Procedia- Social and Behavioral Sciences, Vol. 35, pp.9-22.

Marans, R.W. and Stimson, R. (2011) (Eds).Investigating Quality of Urban Life - Theory, Methods and Empirical Research.EBook. Springer Science + Business Media

Maslow, A. (1954). Motivation and Personality. New York: Harper. 
McCrea, R., Stimson, R., and Marans, R.W. (2011). The Evolution of Integrative Approaches to the Analysis of Quality of Urban Life, in Marans, R.W., and Stimson, R. (Eds) Investigating Quality of Urban Life - Theory, Methods, and Empirical Research. EBook.Springer, pp.77-106.

Mohit, M.A. (2014). Present Trends and Future Directions of Quality of Life . Procedia - Social and Behavioral Sciences, vol. 153, pp.655-665.

Mohit, M.A. (2013a). Quality of Life in Natural and Built Environment - An Introductory Analysis.Procedia - Social and Behavioral Sciences, vol. 101, pp.33-43.

Mohit, M.A. (2013b). Objective Analysis of Variation in the Regional Quality of Life in Malaysia and its Policy Implications.Procedia - Social and Behavioral Sciences, vol. 101, pp.454-464..

Mohit, M.A. and NurulNazyddah (2011).Social housing program of Selangor Zakat Board of Malaysia and housing satisfaction. Journal of Housing and the Built Environment, 26 (2): 143-164

Mohit, M.A., Mansor Ibrahim and YongRazidah Rashid (2010). Assessment of residential satisfaction in newly designed public low-cost housing in Kuala Lumpur, Malaysia. Habitat International, 34(1): 18-27.

Rapley, M. (2003).Quality of Life Research: A Critical Introduction. London: Sage Publications.

Raphael, D., Renwick, R., Brown, I., Steinmetz, B., Sehdev, H. And Phillips, S. (2001). Making the links between community structure and individual well-being: Community quality of life in Riverdale, Toronto, Canada.Health and Place, 7, pp. 179-196.

Schalock, R.L. (2004). Concept of Quality of Life, Journal of Intellectual Disability Research, 48(3): 206- 216.

Sirgy, M.J. (1995). Developing a Life Satisfaction Measure Based on Need Hierarchy Theory. In Sirgy, M.J., and Samli, A. C. (Eds).New Dimensions in Marketing/ Quality-of-Life Research.West Port, CT06881: Quorum Books, pp.3-26.

Sirgy, M.J. (1996). Strategic Marketing Planning guide by the Quality of Life.Journal of Business Ethics, 15, pp. 251259.

Sirgy, M.J. (2001). Handbook of quality-of-life research. Netherlands: Kluwer Academic Publishers.

Sirgy, M.J., and Lee, D.J. (2006).Well-being - Encyclopedia of Business Ethics and Society. Thousand Oaks: Sage Publications.

TAC Social Issues Subcommittee (2004).The social component of community sustainability: a framework user's guide. Canada: Greater Vancouver Regional District.

UN-HABITAT (2012). State of the World's Cities 2012/2013: Prosperity of Cities. Nairobi: UN-HABITAT.

WHOQOL Group (1998). The World Health Organization Quality of Life Assessment (WHOQOL): development and general psychometric properties, Social Science and Medicine, 46, 12: 1569-85. 